\title{
RADIOELEMENTS DISTRIBUTION IN GABAL ABU-MESAID AREA, NORTH EASTERN DESERT, EGYPT
}

\author{
A. ABU-DEIF, L. M. NOSSAIR, M. A. EI-TAHIR and H. I. A. FARAG
}

Nuclear Materials Authority, Cairo, Egypt

- Geology Department, South Valley University, Qena, Egypt.

(Received: 11 September 2007)

\begin{abstract}
A suite of volcanic and plutonic rocks represent the products of Pan-African orogeny; constitute the major litho-tectonic units of Gabal Abu-Mesaid area, in the northern part of the Eastern Desert. These Petro-tectonic units are the syn-tectonic older granitoids, mature arc to continental arc Dokhan Volcanics and the associated pyroclastics as well as the widely distributed Post- to late-tectonic younger granites and the post-granite dykes. The older granitoid recorded in the study area, is represented by granodiorites that is tectonically described as syn-tectonic plutonites. Dokhan volcanics demonstrate a wide spectrum of varieties. These rocks are andesites associated with rhyolites and andesitic tuffs, agglomerates as well as ignimbrites. Younger granites can be differentiated into two types namely: the finegrained biotite granites and the medium-to coarse- grained hornblende biotite granites.
\end{abstract}

Radiometric survey carried out on the rock exposures of G. AbuMesaid area reveals that the younger granitic rocks have the highest radioactivity levels. They show average total-gamma radioactivity of $40 \mathrm{Ur}$ for the fine-grained biotite granites and $31 \mathrm{Ur}$ for the medium-to coarse-grained hornblende biotite granites. It is noticed also that, felsic dykes and some pegmatites related to the younger granites have high radioactivity. Generally, felsic associations have totál gamma-radioactivity values (15 to $50 \mathrm{Ur}$ ) higher than mafic associations (10 to $21 \mathrm{Ur}$ ). Granodiorites have average total gamma-radioactivity of $26 \mathrm{Ur}$. Dokhan volcanics have the lowest average of total gamma- radioactivity (13 Ur).

Distribution of uranium and thorium in the analyzed samples shows that fine-grained biotite granites have average eU content of 14.7 $\mathrm{ppm}$ and $\mathrm{eTh}$ content of $26.5 \mathrm{ppm}$. The average eU-content for the hornblende biotite granites is $6.8 \mathrm{ppm}$ and eTh $20.6 \mathrm{ppm}$. Granodiorites samples have average $\mathrm{eU}$ and $\mathrm{eTh}$ contents of 3.8 and $9.2 \mathrm{ppm}$ respectively. Average contents of $\mathrm{eU}$ and $\mathrm{eTh}$ in andesites are the lowest ( 1.6 and $5.4 \mathrm{ppm}$ respectively).

\section{Introduction}

The present work deals with the distribution of radioelements in G. Abu- Mesaid area in the north Eastern Desert of Egypt (Fig. 1). The area is located between latitudes $27^{\circ} 17^{\circ}-27^{\circ} 26^{\circ} \mathrm{N}$ and longitudes $33^{\circ} 15^{\circ}-33^{\circ} 22^{\circ} \mathrm{E}$, and covering an 
area of about $160 \mathrm{~km} 2$. It is mainly covered with late Precambrian rocks, characterized by moderate to low rugged hills.

G. Abu-Mesaid is a NNW elongated younger granitic intrusion occupying an area of about $80 \mathrm{~km} 2$, with an elevation peak of $615 \mathrm{~m}$ above mean sea level. The area is scarcely populated by nomadic Bedouins pasturing goats and camels

Systematic radiometric survey has been carried out on the various rock exposures. Gamma measurements on the rock exposures were collected and treated to get statistical parameters. Furthermore, some selected samples from the various rock units were radiometrically analyzed using multi-channel gammaray spectrometer (Gad-6 gamma-detector) to determine their equivalent uranium and thorium contents (eU and eTh in $\mathrm{ppm}$ ) as well as their potassium ( $\mathrm{K} \%)$ contents.

\section{GEOLOGIC OUTLINE}

G. Abu-Mesaid area represents a part of the basement complex in the north Eastern Desert of Egypt. It is mainly covered with older granitoids, Dokhan Volcanics and younger granites. Rocks distribution as well as their mutual field relations and contacts are shown in (Fig. 1). Based on field observation and petrographic studies (Farrag, 2003), the main rock units encountered in G. AbuMesaid area can be arranged in the following geological sequence starting from the oldest: granodiorites, Dokhan Volcanics, younger granites. In the following a brief account for the essential geological features of the main recorded rock units:

Granodiorites are of grey colour and show well developed surface exfoliations. Kaolinitization and epidotization represent the main alteration features. They are traversed by felsic and mafic dykes with some quartz veins (Fig. 1), mostly following NE-SW with some deviation to E-W.

Dokhan Volcanics are represented by a thick sequence of lava flows of intermediate to acidic composition, together with a few intercalations of pyroclastics represented mainly by tuffs with locally distributed volcanic breccias. A few sheets or small lenticular masses of very fine-grained violet ignimbrite are also encountered especially along the eastern periphery of $G$. Dokhan. The volcanic rocks in the study area can be differentiated into: 1) andesites and their pyroclastics rock and 2) felsic volcanic rock sequence

The younger granites intrude the previously described rocks through intrusive sharp contacts and sometimes form hybrid contact zones with the granodiorites. On the reverse, they are intruded by felsic and mafic dykes.

The younger granites in G. Abu-Mesaid area are discrinminated into biotite granites and hornblende biotite granites. The biotite granites represent the most widespread rock variety in the study area (Fig. 1). They are invaded by numerous quartz veins and veinlets.

The hornblende biotite granites are medium to fine-grained, pink in colour. They occur as low relief small hills (hardly to separate on the map) along $W$. Sedra and W. Kufrah. These granites intrude the Dokhan volcanics in the form of dykes and offshoots. 
The post granite dykes occur as swarms of felsic and mafic ones as well as quartz veins cutting all the above mentioned rock units in the area. These rocks vary in thickness from half a meter to several meters and some extend for several kilometres. They form parallel swarms striking mainly in NE to ENE, E-W and NW trends (Fig. 1) with vertical to steep inclination. Felsic dykes include the granite porphyries, rhyolites, felsites, pegmatites and aplites, in addition to quartz veins. Mafic dykes are represented by andesite, dolerite and basalt.

\section{RADIOACTIVITY}

The gamma-ray scintillometer, model GR-110 was used for the field radiometric measurements, giving the radioactivity of the rock in terms of count per second (cps). The gamma-detector was calibrated on the calibration pads available at NMA using Gad-6 multi spectral gamma-detectors to convert the cps readings into the international unit of measurement known as "unit of radio element concentration". This unit is equal to $1 \mathrm{ppm} U$ or $0.6 \mu \mathrm{R} / \mathrm{h}$ and simply denoted as Ur (Grasty and Darnley, 1971 and Darnley et al., 1979). This was done, by special software computer program, using the calibration parameters and calibration factor data.

In G. Abu-Mesaid area, a systematic radiometric survey has been carried out on the various rock exposures. Gamma measurements on the rock exposures were collected and treated to get statistical parameters. The arithmetic mean (XI), standard deviation (S) and coefficient of variation (CV) following Neter et al., (1978) were calculated (Table 1). Furthermore, some selected samples from the various rock units were radiometrically analyzed using multi-channel gamma-ray spectrometer to determine their equivalent uranium and thorium contents ( $\mathrm{eU}$ and eTh in ppm) as well as their potassium ( $\mathrm{K} \%$ ) contents (Table 2 ).

Table (1): Summary of statistical values for total gamma-radioactivity measurements, G. AbuMesaid area

\begin{tabular}{lllllll}
\hline & \multicolumn{3}{l}{ Total radioactivity in Ur } & & & \\
\cline { 2 - 5 } Rock types & No. & From & To & (X) in Ur & (S) & (CV) \\
\hline Granodiorites & 62 & 21 & 32 & 26 & 7 & 26.9 \\
Dokhan volcanics & 70 & 8 & 32 & 13 & 4.5 & 34.6 \\
Hornblende biotite granites & 60 & 25 & 40 & 31 & 11 & 35.4 \\
Biotite granites & 190 & 30 & 60 & 40 & 10 & 31.8 \\
Felsic dykes and pegmatites & 198 & 15 & 50 & 31 & 9.4 & 35.0 \\
Mafic dykes & 41 & 10 & 21 & 13 & 4.5 & 40.9 \\
\hline
\end{tabular}

No. $=$ Numbers $X^{\prime}=$ Arithmetic mean $S=$ Standard deviation $\quad C V=$ Coefficient of variation 


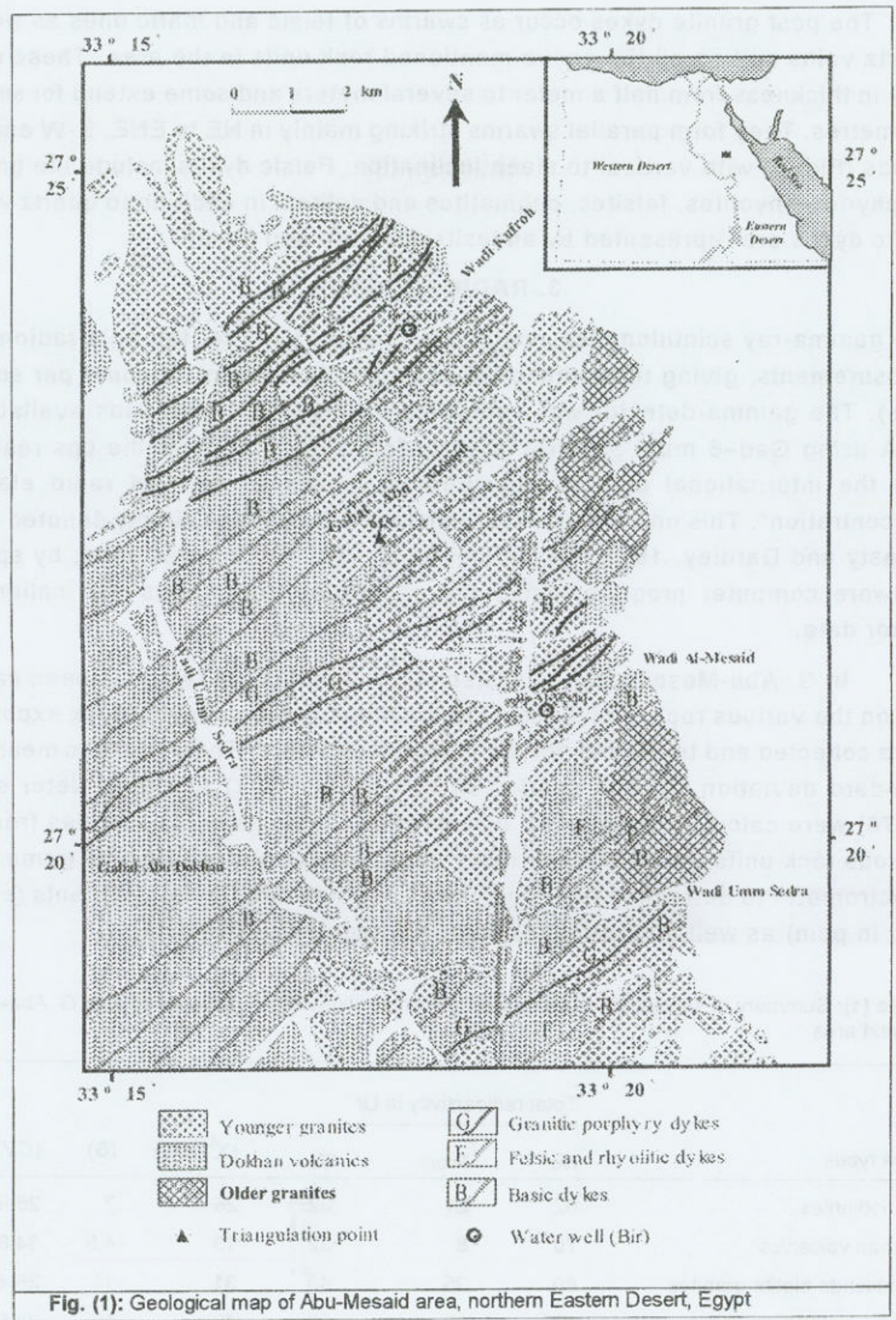

\subsection{Total gamma-radioactivity}

Table (1) shows the calculated statistical parameters of the total gammaradioactivity for the different rock exposures in G. Abu-Mesaid area. It is clear from this table that the younger granite rocks have high gamma-radioactivity, from which the fine-grained biotite granites have the highest values ( $40 \mathrm{Ur}$ ) among all rock typezs. On the other hand, Dokhan volcanics as well as mafic dykes' exhibit the lowest level of gamma-radioactivity (13 Ur). The post granitic dykes, 
represented by both felsic and mafic types, showed gamma-radioactivity varying from one to another depending on their mineralogical compositions as well as the type of the host rocks. Generally, felsic associations have gamma-radioactivity values ( 15 to $50 \mathrm{Ur}$ ) higher than mafic associations (10 to $21 \mathrm{Ur}$ ). Granodiorites have total gamma-radioactivity ranging from $21 \mathrm{Ur}$ for the mafic rich varieties to $32 \mathrm{Ur}$ for granodiorites of normal composition, with an average of $26 \mathrm{Ur}$.

\subsection{Radiometric analysis}

Variability in radioelement contents of 33 samples represented the different rock exposures in G. Abu-Mesaid area are given in table (2). The fine-grained biotite granites have the highest level of gamma-radioactivity among rocks cropping out in the area, while the andesitic rocks are the lowest; except the ignimbrites which show relatively high contents of radioelements concentration (Table 2). The biotite granites show average of $14.7 \mathrm{ppm}$ for uranium and $26.5 \mathrm{ppm}$ for thorium, with eU/eTh ratio of 0.65 . The hornblende biotite granites show average Ucontents of $6.8 \mathrm{ppm}$ and $\mathrm{Th}$ of $20.6 \mathrm{ppm}$, with eU/eTh ratio of 0.32 . The granodiorites samples, of normal composition, give averages of 3.8 and of 9.2 $\mathrm{ppm}$ for uranium and thorium respectively.

\section{GEOCHEMISTRY of $U$ and Th}

Understanding of geochemical behaviour of $U$ and Th during crystallization can be demonstrated by plotting $U$, Th and $U / T h$ ratio against differentiation index (D.I) of Thronton and Tuttle (1960). The relation between $U$ and Th may indicate enrichment or depletion of $U$ because $T h$ is chemically stable. Normally; thorium is three times as abundant as uranium in all rock types (Rogers and Adams, 1969). When this ratio is disturbed, it indicates a depletion or enrichment of uranium. If the U/Th ratio increases strongly with uranium but not with thorium, post magmatic redistribution of uranium is suggested and if $U / T h$ is inversely correlated with thorium, the radioelement distribution is, at least in part, governed by magmatic processes (Charbonneau, 1982). The geochemical behaviour of $U$ and $T h$ in both older and younger granites of the studied area can be examined in different waýs as follows:

\subsection{U -Differentiation index (D.I.) variation diagrams}

Figure (2.a and b) illustrates the U-Th-D.I. variation diagrams'for the studied granitic rocks. It is clear that, $U$ and Th show an increasing trend with D.I., suggesting magmatic control of $U$ concentration. This conclusion is further confirmed by using $T h / U$ ratio against D.I. (2.c) that shows rather negative relation in granodiorites, biotite granites and hornblende biotite granites.

\subsection{U-Th variation diagrams}

Correlation between uranium and thorium on the constructed diagram (Fig. 2.d) indicates that magmatic processes played an important role in the uranium distribution. U/Th ratios increase strongly with uranium in both older and younger granitic rocks (Fig. 2.e), and inversely with thorium in granodiorites (Fig. 2.f). This is probably due to post-magmatic redistribution of uranium in granodiorite rocks. 
Table (2): Results of radiometric analyses of some samples collected from G. Abu-Mesaid area

\begin{tabular}{|c|c|c|c|c|c|}
\hline Rock type & Sample No. & $\begin{array}{c}\mathrm{eU} \\
(\mathrm{ppm})\end{array}$ & $\begin{array}{c}\text { eTh } \\
\text { (ppm) }\end{array}$ & $\begin{array}{l}K \\
(\%)\end{array}$ & eU/eTh \\
\hline & $46 \mathrm{~A}$ & 4 & 10 & 2.50 & 0.40 \\
\hline & 48 & 2 & 9 & 2.83 & 0.22 \\
\hline \multirow[t]{9}{*}{ Granodiorites } & 67 & 5 & 12 & 2.90 & 0.42 \\
\hline & 69 & 4 & 7 & 4.14 & 0.57 \\
\hline & 70 & 5 & 15 & 2.56 & 0.30 \\
\hline & $99 \mathrm{~A}$ & 4. & 12 & 2.48 & 0.30 \\
\hline & & Avg. $=3.8$ & Avg. $=9.2$ & Avg $=2.9$ & Avg. $=0.36$ \\
\hline & $14 B$ & 1.5 & 6 & 1.27 & 0.25 \\
\hline & $17 \mathrm{~B}$ & 2 & 5 & 2.52 & 0.40 \\
\hline & $43 A$ & 1.7 & 8 & 3.87 & 0.21 \\
\hline & $65 A$ & 1.5 & 4 & 1.32 & 0.37 \\
\hline \multirow{6}{*}{ Andesites } & 94 & 1.4 & 3 & 0.27 & 0.46 \\
\hline & 99 & 1.5 & 7 & 3.02 & 0.21 \\
\hline & 103 & 1.8 & 6 & 0.72 & 0.30 \\
\hline & & Avg $=1.6$ & Avg: $=5.4$ & Avg $=1.8$ & Avg $=0.3$ \\
\hline & $94 \mathrm{~A}$ & 6 & 15 & 1.24 & 0.40 \\
\hline & $94 \mathrm{~B}$ & 8 & 15 & 0.80 & 0.53 \\
\hline \multirow{5}{*}{ Ignimbrites } & $96 \mathrm{~A}$ & 7 & 18 & 1.85 & 0.38 \\
\hline & $96 \mathrm{~B}$ & 5 & 18 & 3.87 & 0.27 \\
\hline & 97 & 7 & 16 & 4.00 & 0.43 \\
\hline & & Avg. $=6.6$ & Avg. $=16.4$ & Avg. $=2.3$ & Avg $=0.40$ \\
\hline & 12 & 6 & 18 & 2.85 & 0.33 \\
\hline \multirow{10}{*}{ Hornblende biotite granites } & 17 & 5 & 17 & 3.84 & 0.29 \\
\hline & 101 & 7 & 21 & 3.33 & 0.33 \\
\hline & 102 & 7 & 23 & 2.92 & 0.30 \\
\hline & 105 & 9 & 24 & 3.05 & 0.37 \\
\hline & & Avg $=6.8$ & $A v g=20.6$ & $A v g=3.2$ & Avg. $=0.32$ \\
\hline & 22 & 12 & 24 & 3.84 & 0.50 \\
\hline & $26 \mathrm{~A}$ & 7 & 20 & 3.67 & 0.35 \\
\hline & 33 & 17 & 30 & 3.54 & 0.57 \\
\hline & 36. & 14 & 23 & 3.28 & 0.61 \\
\hline & 43 & 17 & 31 & 2.87 & 0.55 \\
\hline \multirow[t]{6}{*}{ Biotite granites } & 45 & 15 & 24 & 2.88 & 0.63 \\
\hline & 49 & 16 & 25 & 3.78 & 0.64 \\
\hline & 51. & 14 & 29 & 1.61 & 0.48 \\
\hline & 79 & 18 & 33 & 3.57 & 0.55 \\
\hline & 80 & 17 & 26 & 3,41 & 0.65 \\
\hline & & Avg. $=14.7$ & Avg. $=26.5$ & Avg. $=2.9$ & Avg. $=0.55$ \\
\hline
\end{tabular}

\section{3. $\mathrm{U}-\mathrm{Fe}_{2} \mathrm{O}_{3}$ and $\mathrm{U}-\mathrm{P}_{2} \mathrm{O}_{5}$ variation diagrams}

Figure (2.g) shows weakly positive relationship between $U-\mathrm{Fe} 2 \mathrm{O} 3$ in granodiorites, on the other hand the younger granites, especially in hornblende biotite granite, the relation becomes strongly positive. This relationship indicates that uranium enrichment was not only controlled by primary magmatic processes but also by secondary processes. Shalaby (1995) and Moharem (1997) suggested that there is a positive correlation between the degree of ferrugination and the intensity of uranium content. This may be due to the ability of iron oxides to adsorb uranium from circulating solutions. Figure (2.h) shows poor sympathetic relation between $U$ and $\mathrm{P} 2 \mathrm{O} 5$ in granodiorites; furthermore the younger granites the relation is positive. This relationship indicates the presence of $U$ in the apatite mineral.

\subsection{U $\mathrm{U}$ r variation diagram}

The correlation between $U$ and $Z r$ in granodiorites is weakly negative, whereas $U$ shows positive correlation with $\mathrm{Zr}$ in both types of younger granites (Fig. 2.i). The positive correlation between $U$ and $Z r$ may also indicates the presence of $U$ in the 
crystal lattice of the zircon mineral, which agrees with the concentric zones of different colours that exhibited by zircon crystals.

\section{5. $\mathrm{U}-\mathrm{Pb}$ variation diagram}

Figure (2.j) shows the negative correlation between $\mathrm{U}$ and $\mathrm{Pb}$ in granodiorites; on the other hand it is more or less positive with the two types of younger granites. These positive relations are probably due to the radiogenic lead, which is derived by the decay of uranium.

\section{6. $\mathrm{U}-\mathrm{Rb}$ and $\mathrm{U}-\mathrm{Nb}$ variation diagrams}

The correlation between $U$ and $R b$ in granodiorites is weakly positive. On the other hand it is positive in both biotite granites and hornblende biotite granites (Fig. 2.k) indicating $U$-enrichment due to magmatic origin. Figure (2.1) shows the positive relation between $U$ and $\mathrm{Nb}$ in biotite granites and hornblende biotite granites, while the correlation is weakly negative in granodiorites indicting $U$ enrichment with magmatic differentiation. Also $\mathrm{Rb}$ and $\mathrm{Nb}$ behave incompatibly in granitic melts, so if $U$ was controlled by magmatic process these elements would be expected to increase.

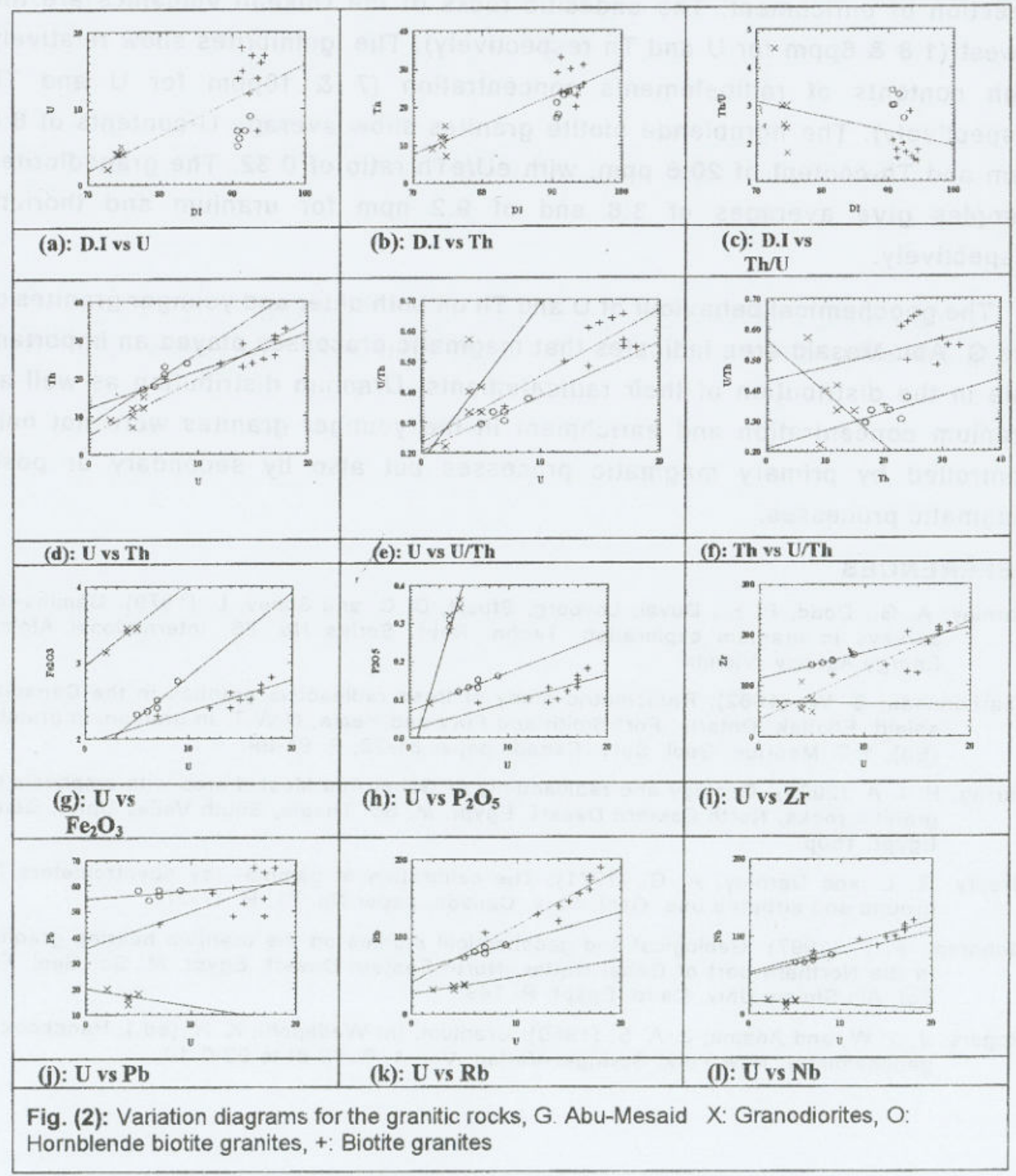




\section{CONCLUSION}

Field radiometric measurements for the different rocks exposed at G. Abu-Mesaid area showed that the younger granites have high total gamma-radioactivity (from 25 to $60 \mathrm{Ur}$ ), from which the fine-grained biotite granites have the highest values (avg. $40 \mathrm{Ur}$ ) among all rock types. On the other hand, Dokhan Volcanics as well as mafic dykes exhibit the lowest level of gamma-radioactivity (avg. 13 Ur). The felsic dykes have gamma-radioactivity values (avg. $31 \mathrm{Ur}$ ) higher than mafic associations. Granodiorites have total gamma-radioactivity ranging from 21 to 32 $\mathrm{Ur}$, with an average of $26 \mathrm{Ur}$.

Radioelement contents of the analyzed samples of G. Abu-Mesaid area show that the fine-grained biotite granites are the highest in rdioelement contents. They have average of $14.7 \mathrm{ppm}$ for uranium and $26.5 \mathrm{ppm}$ for thorium, with eU/eTh ratio of 0.55 . This means redistribution of $U$ in this type of granites in the direction of enrichment. The andesitic rocks of the Dokhan volcanics are the lowest (1.8 \& 6ppm for $U$ and Th respectively). The ignimbrites show relatively high contents of radioelements concentration $(7 \& 16 \mathrm{ppm}$ for $U$ and $T h$ respectively). The hornblende biotite granites show average U-contents of 6.8 $\mathrm{ppm}$ and Th-content of $20.6 \mathrm{ppm}$, with eU/eTh ratio of 0.32 . The granodiorites samples give averages of 3.8 and of $9.2 \mathrm{ppm}$ for uranium and thorium respectively.

The geochemical behaviour of $U$ and $T h$ on both older and younger granites of the G. Abu-Mesaid area indicates that magmatic processes played an important role in the distribution of their radioelements. Uranium distribution as well as uranium concentration and enrichment in the younger granites were not only controlled by primary magmatic processes but also by secondary or postmagmatic processes.

\section{REFERENCES}

Darnley, A. G.; Dodd, P. H.; Duval, Lovborg, Stuart, D. C. and Simov, L. (1979): Gamma-ray surveys in uranium exploration. Techn. Rept. Series No. 86. International Atomic Energy Agency. Vienna.

Charbonneau, B. W. (1982): Radiometric study of three radioactive granites in the Canadian shield: Ellotlak, Ontario, Fort Smith and Fury and Hecla, N.W.T, in uranium in granite, (Ed), Y.T. Maurice; Geol. Surv. Canada paper 81-23, P. 91-99.

Farrag, H. I. A. (2003): Geology and radioactivity of Gabal Abu Mesaid area with emphasis on granitic rocks, North Eastern Desert, Egypt. M. Sc. Thesis, South Valley Univ., Qena, Egypt, 150p.

Grasty, R. L. and Darnley, A. G. (1971): The calibration of gamma- ray spectrometers for ground and airborne use. Geol. Surv. Canada, paper No. 71, P. 17-27.

Moharem, A. F. (1997): Geological and geochemical studies on the uranium bearing granites in the Northern part of Gabal Gattar, North Eastern Desert, Egypt. M. Sc. Geol. Fac Sci, Ain Shams Univ. Cairo, Egypt. P. 149.

Rogers, J. J. W. and Adams, J. A. S. (1969): Uranium. In: Wedepohl, K. H. (ed.), Handbook of geochemistry. New York, Springer-Verlag, Vol. 4, P. 92 BI to 92 C 10. 
Shalaby, M. H. (1995): New occurrence of uranium mineralization G-V II, Gabal Gattar uranium prospect, North Eastern Desert, Egypt. Bull. Fac. Sci. Alex. Univ., Vol. 9, P. $145-155$.

Thoronton, C. P., and Tuttle, O. F. (1960): Chemistry of igneous rocks, Differentiation index. Am. J. Sec., 258, P. 664-684.

\section{توزبع العناصر المشعة في منطقة جبل أبومساعيد، شمال الصحراء الشرقية، مصر.}

علي أبوضيف أحمد، لطفي مصطفى نصير، محمد علي الطاهر*، وحسن اسماعيل أحمد فراج

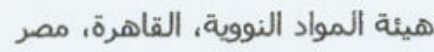

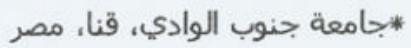

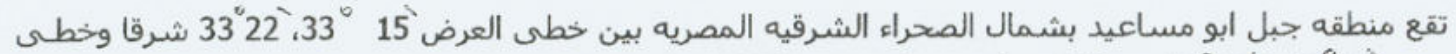

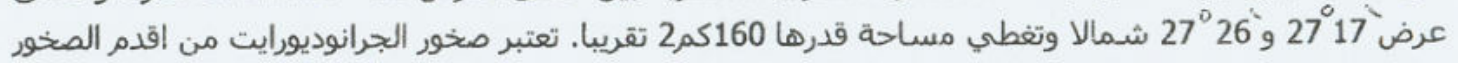

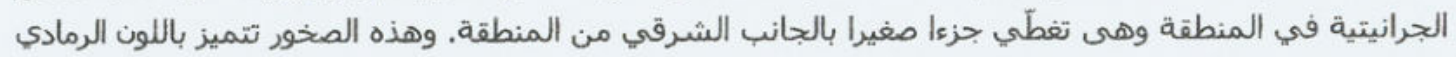

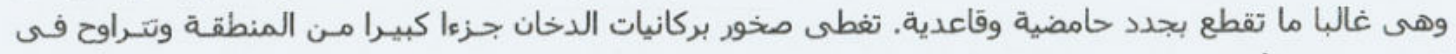

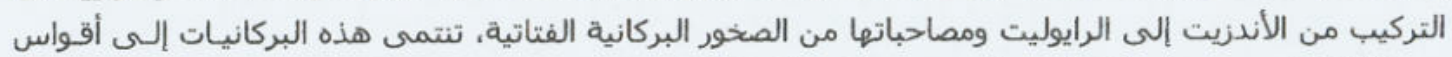

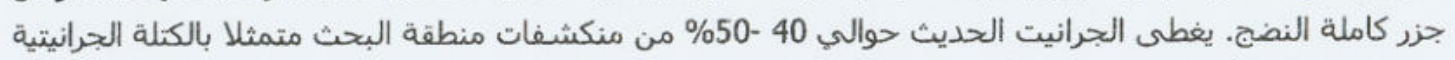

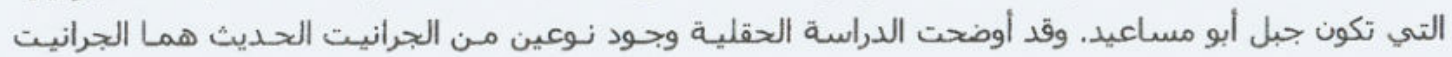

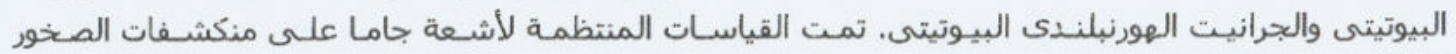

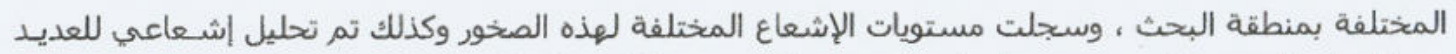

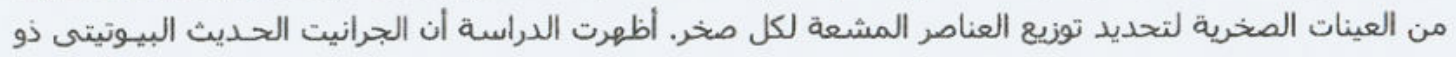

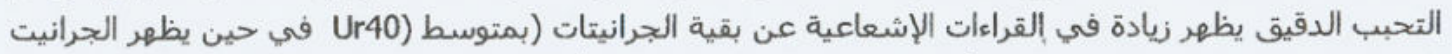

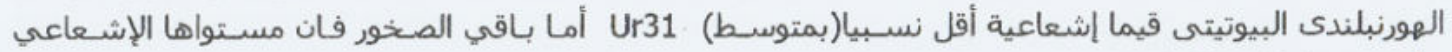
يتأرجح حول القيم الطبيعية . 